\title{
„Kapitalismus blahobytu“ a „stát blahobytu“. Německé diskuze kapitalismu v perspektivě sociální péče o dělnictvo
}

\author{
TOMÁŠ GECKO*
}

\author{
"Welfare Capitalism" and the "Welfare State". German Discussions on Capitalism \\ from the Standpoint of the Social Care of the Working Class
}

\begin{abstract}
The term capitalism can be considered to be both a designation of a specific historical epoch and an analytical tool in the humanities. This case study focuses on the second level of the term, specifically the usage of capitalism as an aid in the analysis of state and industrial enterprise strategies aiming at the social care of the working class. The text raises the question of whether a developed theoretical system of entrepreneurial strategies towards the working class as the discourse of welfare capitalism, for example, in the Anglo-Saxon countries did emerge in German-language historiographical discourse. Although the German scene worked with an associated term (Wohlfahrtskapitalismus), its intentions were fundamentally different to those of its Anglo-Saxon counterpart, due to the extraordinary emphasis on the state, which emerged as the chief guarantor behind the institutional basis of modernization processes in the economic and sociological theories of the German historical school. Although the postwar German Ordoliberalism vigorously denied primacy to central administration within the economy, the synergy between the state and social policy was always present at the theoretical and practical level. In this context the entrepreneurial class only had limited space to develop generally autonomous social policy, which was legislatively covered by state authorities in Central Europe.
\end{abstract}

Keywords: welfare capitalism; social state; German historical school; Ordoliberalism; business strategies

DOI: $10.14712 / 23363525.2020 .7$

Použití pojmu „kapitalismus“v humanitním výzkumu s sebou nese jistou kontroverzi. Důvodem nejsou pouze terminologické spory, které tento koncept doprovázejí, ale také jeho zatížení ideologickými a dialektickými debatami o fungování moderního socioekonomického systému. Ty se odehrály již v 19. století a s obzvlášt vysokou intenzitou pak probíhaly ve druhé polovině 20 . století v souvislosti s propagandistickými boji na pozadí studené války. Navzdory - anebo právě kvưli - této kontroverzi je diskurz kapitalismu velmi bohatý [Hilger 1982: 399-454]. Zejména v posledních letech se pojem těší rostoucí pozornosti humanitních vědců. Obnovení badatelského zájmu lze přičíst hospodářskému, sociálnímu a politickému vývoji na přelomu druhého a třetího tisíciletí. Počínaje devadesátými lety 20. století procházel koncept renesancí. Ta souvisela s ukončením studené války, postupující globalizací a vzestupem i následným zpochybněním neoliberálního modelu tržního systému [Kocka 2016: 1-4]. Byla to pak především hospodářská krize z let 2007/2008, která stimulovala hledání nových paradigmatických př́stupů k vývoji

* PhDr. Tomáš Gecko, Ph.D., Ústav hospodářských a sociálních dějin Filozofické fakulty Univerzity Karlovy, nám. Jana Palacha 2, 11638 Praha 1. E-mail: tomas.gecko@ff.cuni.cz 
moderního socioekonomického uspřádání lidské společnosti. Tyto trendy doprovázelo upozadění konkurenčně orientovaného kapitalismu na úkor jeho kooperativněǰš́ch forem [Schröter 2013: 994-999]. Zjednodušeně řečeno, opět začalo pátrání po „správném“ modelu kapitalismu, který by eliminoval nerovnováhy moderního hospodářství v alokaci zdrojů a zároveň efektivně skloubil tržní systém s blahobytem obyvatelstva [Kromphardt 2015: 293-297].

Cílem studie je zodpovědět, jakých konotací nabývaly v německojazyčném prostředí 19. a 20. století diskuze o kapitalismu v návaznosti na sociální péči podnikatelstva o průmyslové dělnictvo, a zda směřovaly ke vzniku podobných historiografických př́stupů, jaké tvořila anglosaská soustava „kapitalismu blahobytu“ (welfare capitalism). Předpokladem pro nalezení východiska je propojení zkoumané tematiky s obsahem termínu „stát blahobytu" (Wohlfahrtsstaat), který se jakožto etatický režim bismarckovského a wilhelmovského Německa dostával do pnutí s paternalistickými strategiemi korporátního sektoru vůči dělnictvu.

\section{Základní terminologická východiska: Kapitalismus a Wohlfahrtskapitalismus}

Kapitalismus může být jednak označením pro konkrétní historickou epochu spojenou s fungováním specifického socioekonomického systému, jednak analytickým nástrojem humanitních věd. Počátky kapitalismu coby procesu, jímž vstupují hmotné a nehmotné statky (kapitál) do výroby, lze sledovat až ke starověkému a středověkému kupeckému systému (Kaufmannskapitalismus), který nebyl unikátním pouze pro západní civilizační okruh. Tyto velkoobchodnické aktivity souvisely s pronikáním na vzdálené trhy a riskantními, vysoce rentabilními přesuny finančního i komoditního kapitálu. Avšak teprve v evropském prostředí se na prahu moderní doby kapitalismus dokázal propojit s polem politické moci takovým způsobem, aby došlo $\mathrm{k}$ fundamentální změně sociální struktury lidské společnosti i jejích hodnotových a mentálních vzorců [Braudel 1979; Braudel 1999; Howard 1985: 470]. Právě pro periodické zachycení této historické epochy bývá v humanitních vědách někdy používán pojem kapitalismus. Představitel mladší generace německé historické školy Werner Sombart (1863-1941) takto rozeznával tři vývojové fáze kapitalismu, pod nímž si představoval evropský socioekonomický systém 18.-20. století: 1) Raný kapitalismus (Frühkapitalismus), ztotožnitelný s merkantilistickou politikou aktivní obchodní bilance a stimulováním manufakturní výroby, mu sloužil jako protiklad feudální ruční práci; 2) Vrcholný kapitalismus (Hochkapitalismus) spojoval s rozvojem strojní výroby, svobodného podnikání a volného obchodu; 3) Tato perioda trvala až do první světové války, kdy se zrodil pozdní kapitalismus (Spätkapitalismus), jenž souvisel se státními intervencemi do ekonomiky a masivní koncentrací výroby, spojenou s monopolizací trhu a procesem kartelizace [Sombart 1902-1928].

Ačkoliv bylo slovo kapitalismus v odborné literatuře použito již roku 1805 Juliem von Sodem [Linden 2011: 164], jeho analytická aplikace se datuje teprve do druhé poloviny 19. století, kdy s touto koncepcí začali pracovat francouzští intelektuálové. ${ }^{1}$ Ve stejné době

\footnotetext{
1 Např́klad Pierre Leroux (1797-1871), Louis Blanc (1811-1882) a Pierre Joseph Proudhon (1809-1865), kteří všichni vycházeli z odlišných ideologických a teoretických pozic.
} 
si pojem pozvolna osvojovalo také německé prostředí. ${ }^{2}$ Diskurz kapitalismu rozlišuje několik základních modelů, které se následně štěpí na mnoho komplexních podmnožin. Kapitalismus se ve svém starším pojetí terminologicky vztahoval výhradně k soukromému vlastnictví jednotlivce (Eigentumskapitalismus), výrobní koncentrace podnikatelských subjektů však kladla nároky na vytváření stále sofistikovanějších firemních hierarchií vyžadujících manažerské vedení (Korporativkapitalismus). Do hry brzy vstoupil finanční sektor svými úvěrovými strategiemi, následovaný státem a jeho intervencionistickou politikou (Finanzkapitalismus, Organisierter Kapitalismus) [Kocka 2013: 9-25]. Opomenout nelze ani námezdní práci, která dala vzniknout zcela nové společenské skupině, a to průmyslovému dělnictvu, na něž se zaměřila anglosaská teoretická soustava „welfare capitalism“. Cílem posledně jmenovaného metodologického proudu bylo zasadit podnikatelské strategie vưči zaměstnancům do širších souvislostí dělnické a sociální otázky. Paradigma welfare capitalism se brzy rozpadlo do množství navzájem více či méně kompatibilních premis, analyzujících vzorce chování podnikatelských subjektů, většinou za účelem stabilizace interakce zaměstnavatel-zaměstnanec. Důvody pro budování sociálního zabezpečení na úrovni podniků však byly mnohem širší a mohly sahat až k paternalistickému přivázání pracovní síly či komerční prezentaci firmy ve veřejném prostoru za účelem obchodní reklamy [Herc 2020].

Kontinentální evropské prostředí absentuje souvislý diskurz kapitalismu, který by se $\mathrm{v}$ analytické rovině zaměřil na strategie průmyslu vůči dělnictvu, jako je tomu v př́padě anglosaského „welfare capitalism“. To ovšem neznamená, že by chyběla početná literatura o průmyslovém paternalismu a altruistickém jednání podnikatelstva [Berghoff 1997: 167-204; Ellerkamp 1991: 137-140]. Totéž ostatně platí i o dalších civilizačních oblastech, jelikož pevné institucionální ukotvení vzájemné interakce bylo po nastartování druhé vlny industrializace (druhé průmyslové revoluce v poslední třetině 19. století) žádoucí jak pro zaměstnance, tak pro zaměstnavatele, i kdyby jen na úrovni konkrétního podniku. Ve stručnosti lze poukázat na bohatý diskurz japonského průmyslového paternalismu, který tvoří součást širší diskuze o výlučnosti japonského obyvatelstva (Nihondžinron, 日本人論). Cílem japonských průmyslníků bylo konstruovat kvalifikovanou a zároveň loajální pracovní sílu, čehož dosáhli vytvořením složitého systému seniorátního kariérního postupu a celoživotního zaměstnání, jenž úspěšně snížil efektivitu odborového hnutí [Nakane 1970; Morishima 1982]. Ani německojazyčný historiografický diskurz kapitalismu nepracuje s paralelou anglosaského konceptu „welfare capitalism“. Ačkoliv existuje německý ekvivalent tohoto slovního spojení (Wohlfahrtskapitalismus), následující diskuze ukáže, že oba termíny rozhodně nejsou zaměnitelné. Hlavní důvod této diference zřejmě spočíval v mimořádné úloze stř̌edoevropského státu, který svou intervencionistickou politikou přebíral od závěru 19. století iniciativu v řešení sociální otázky, a to na úkor podnikatelstva, jehož manévrovací prostor se zmenšoval. Proč stát tyto strategie volil a jaké konkrétní výsledky si od nich sliboval? Zodpovězení této otázky vyžaduje učinit stručný nástin německého diskurzu „kapitalismu blahobytu“ a „státu blahobytu“.

2 Došlo k tomu skrze práce Johanna Karla Rodbertuse (1805-1874), Alberta Schäffleho (1831-1903) a později i Wernera Sombarta (1863-1941), tedy nikoliv Karla Marxe (1818-1883) a Friedricha Engelse (1820-1895), kteří zpočátku využívali pouze starší termíny kapitál a kapitalista. 


\section{Stát, podnikatel a dělnictvo: Wohlfahrtskapitalismus a Wohlfahrtsstaat}

Koncept volné ruky trhu vlivného skotského ekonoma a filozofa Adama Smithe (17231790), vybízející k minimálním státním zásahům do ekonomiky, nezískal v intelektuálním prostředí Německa 19. století př́liš velkou popularitu. Individuální aktér nebyl vnímán jako zcela autonomní entita, disponující svobodnou volbou strategií, které by byly nezávislé na státních strukturách. Atraktivní byla pouze teze, že povinností administrativy je zajistit institucionální podmínky pro rozvoj hospodářského systému [Wehler 2011: 34-36]. Proč se právě tento faktor ukázal být pro německé prostředí přijatelným, zatímco liberální pojetí klasické politické ekonomie jako celek bylo veskrze odmítáno? Uvedená premisa vykazovala značnou kompatibilitu s modelem novověkého policejního státu (Polizeistaat), v německém diskurzu ztotožňovaném se správním státem (Verwaltungsstaat). Co se pod těmito pojmy skrývá? Osvícenský absolutistický stát 17. a 18. století, jehož cílem byl všeobecný blahobyt a veřejný pořádek, klidně i proti vưli individuálních aktérů. Tento „stát blahobytu a pořádku“ (Wohlfahrts- und Ordungsstaat) vytvářel centrální, hierarchizovanou byrokracii, která opakovaně zasahovala do soukromé sféry subjektů. Individuální svoboda i soukromé vlastnictví se v ideologické rovině musely podřídit ochraně veřejných jistot a udržení disciplíny, tedy nástrojům politiky blahobytu, jež mimo jiné usilovala o zvýšení ekonomického výkonu a posílení daňových výnosů skrze racionalizační a populacionistická opatření (rozšiřování infrastruktury, zakládání manufaktur, unifikace trhu, stimulování populačního růstu a kultivace obyvatelstva). Ačkoliv se tento model centralizovaného státu ocitl během 19. století v důsledku konstitučních reforem na ústupu [Brockhaus 1972: 760], německé intelektuální prostředí si po dlouhou dobu zachovalo značnou míru tolerance k etatickým zásahům do socioekonomického systému (nelze však tvrdit, že by se v německém diskurzu kapitalismu 19. století neprojevovaly i liberální proudy) [Quack 2006: 63-83].

Silnou úlohu státu ve středoevropském hospodářství pomohla legitimizovat hegelovská filozofie, jež propojila smithovskou koncepci volné tržní konkurence s požadavky na budování právní a vzdělávací infrastruktury i moderní dopravní logistiky (železnice, silnice, říční přeprava, telegrafní sítě, pošty apod.). Takto náročný úkol mohla dostatečně rychle splnit jen centrální administrativa, která se např́iště stala garantem efektivní modernizace. Nastíněný vývoj korespondoval se staršími tradicemi kameralismu, jenž si ve stř̌ední Evropě zachoval mnohem silnější pozice než odkaz merkantilismu dále na západě. Propojení importovaného smithovského postulátu volné ruky trhu s domácí hegelovskou filozofií a kameralistickým dědictvím vytvořilo unikátní myšlenkové podhoubí, v němž se zrodila nejstarší generace německé historické školy, která formovala základy německého ekonomického myšlení. ${ }^{3}$ Právě v tomto prostředí se pozvolna formovala představa, že bez státní ochrany je velmi složité zajistit hladký systémový rozvoj kapitalismu. Jen stát mohl garantovat právní jistotu, soukromé vlastnictví, patentovou ochranu, akciové podnikání i hladký průběh zahraničního obchodu [Wehler 2011: 36-39].

Nechybělo mnoho, aby došlo k propojení uvedeného modelu státně-intervencionistického kapitalismu s historickými tradicemi absolutistického státu „blahobytu a pořádku“.

3 Stručně zmínit lze její reprezentanty Bruno Hildebranda (1812-1878), Karla Kniese (1821-1898) či Wilhelma Roschera (1817-1894). 
Uvedenému cíli se nejprve přiblížil právník, sociolog a národohospodář Lorenz von Stein (1815-1890), který se zasloužil o recepci termínu socialismus německým prostředím a rozpracoval první teorie německého „sociálního státu“ (Sozialstaat) [Blasius 1971: 35-51; Schieder 1984: 947-949]. Tento konzervativní právník, jenž mimo jiné proslul jako jeden z myšlenkových otců japonské ústavy Meidži (v platnosti 1889-1947) [Griffis 1910: 125], usiloval o eliminaci nedokonalostí kapitalistického hospodářského systému skrze legislativní mechanismy finančních transferů. ${ }^{4}$ Pojem „sociální stát“, přítomný v německých intelektuálních diskuzích 19. století, se dnes ponejvíce vztahuje k sociálním reformám kancléře Otto von Bismarcka (1815-1898), které usilovaly o snížení rizika občanských nepokojů prostřednictvím finančních transferů na sociální a zdravotní péči [Zudová-Lešková - Voráček 2014: 28]. Avšak praktický rozměr bismarckovské a wilhelmovské politiky měl mnoho společného také s osvícenským „státem blahobytu a pořádku“. Teoretickou legitimizaci tomuto přístupu poskytli příslušníci mladší generace německé historické školy z okolí Verein für Sozialpolitik, stěžejního národohospodářského spolku založeného počátkem sedmdesátých let 19 . století. ${ }^{5}$ Ti volali po pozvolném prohlubování sociálních intervencí státu [Ullmann 1995: 178]. Fakticky tak navázali na Steinovu argumentační linku [Rákosník 2010: 22-23], jen s tím rozdílem, že z praktických důvodů směřovali k pojmu „stát blahobytu“ (Wohlfahrtsstaat). Ten odkazoval k velmi širokému souboru socioekonomických opatření, jejichž společným jmenovatelem byly protiliberální konotace cílící na vytvoření specifického modelu „státního paternalismu“, tj. nevyžádaného vměšování státních úřadů do soukromé sféry dalších subjektů s motivací zajistit blahobyt obyvatel, dokonce i proti jejich vůli [Dworkin 2017].

Mladší generace německé historické školy kladla silný důraz na praktické využití zjištěných poznatků a jejich kompatibilitu s fungováním politického systému [Backhaus 1993/1994: 17], což se odrazilo ve snaze legitimizovat hierarchizované vztahy na makroekonomické i mikroekonomické úrovni. Ačkoliv se někteří př́islušníci německé historické školy stali proponenty státních intervencí do fungování tržního systému na makroekonomické úrovni, v mikroekonomické rovině byla situace mnohem složitější. Určitým segmentům soukromého podnikání dokonce ponechávali větší volnost, než jak činila neoklasická ekonomie a později i neoklasická syntéza v anglosaských zemích. Př́kladem může sloužit pojem „tržní ústava“, pod nímž si lze představit soubor samovolných i cílených regulací, které determinují chování firmy působící na konkrétním trhu (včetně legislativních zásahů veřejné moci a kolektivních smluv ovlivňujících strukturu i výkon trhu, tj. kartelů a syndikátů). Teoretické postuláty Gustava Schmollera (1838-1917), př́slušníka mladší generace německé historické školy, vnímaly tento institucionalizovaný soubor pravidel jako účinný nástroj, jak zajistit samoregulativní fungování ekonomiky skrze eliminaci tržních nedostatků plynoucích z chování dominantních firem. De facto se tak otevíraly dveře soukromé monopolizaci trhu skrze kartely a syndikáty (tento př́istup ostatně disponoval ve středoevropském národohospodářském kontextu silnou legitimitou) i upevňování autority uvnitř firemní hierarchie. Ve vztahu k dělníkovi toto uvažování směřovalo vstříc

4 Lorenz von Stein nebyl jediným, kdo v polovině 19. století s pojmem sociální stát pracoval. Více k problematice odlišných koncepcí sociálního státu a genezi pojmu viz [Rákosník 2012: 324-325; Rákosník - Tomeš 2012: 37-48].

5 Uvedime hlavní představitele, a to Gustava Schmollera (1838-1917), Wernera Sombarta, Lujo Brentana (18441931) a Adolfa Wagnera (1835-1917). 
disciplinaci a rozsáhlé institucionalizované péči o „blahobyt“. Vyústěním těchto strategií měla být schopnost podniku zakročit vůči dělnictvu, pokud se začne chovat „nezodpovědně“. Ačkoliv v takovémto uvažování nechyběl prostor pro osobní svobodu jedince, nejednalo se o natolik podstatné téma, aby jej Schmoller teoreticky výrazněji rozvinul. Obrovský důraz byl naproti tomu kladen na disciplínu jakožto záruku hladkého fungování tržních procesů, čímž se Schmoller podstatně odlišoval od marxistického myšlení [Schneider 1993/1994: 366-370]. Je přitom nasnadě, že disciplinace se nutně nerozvíjela jen na úrovni podniku, ale také skrze aktivity státních úřadů.

Nejenže mladší generace historické školy pomohla teoretickými úvahami legitimizovat přítomnost německého státu v ekonomice (intervence však neměly podoby dirigismu, nýbrž jemných vstupů za účelem institucionální racionalizace) [Engelhardt 2001: 278-279], podařilo se jí rovněž generovat synergie mezi etatickou sociální politikou, hierarchizovaným firemním prostředím a diskurzem kapitalismu. Německý intervencionismus čerpal ze starších tradic policejního státu (Polizeistaat) a usiloval o stabilizaci industriální společnosti v intencích organizovaných forem kapitalismu. Realizace tohoto záměru žádala vybudování početné a efektivní byrokracie, jejíž množství ve skutečnosti expandovalo v Německu podstatně rychleji, než kolik činil procentuální přírůstek populace. Dalším pilírem státního intervencionismu byla policie, která se soustředila na politiku „blahobytu“, pod čímž lze rozumět hlubokou penetraci silových složek do urbánního prostředí a vytváření donucovacích prostředků za účelem vnitřní stabilizace státu. Stát se v sociálních otázkách angažoval skrze pojiššovací systém (úrazové pojištění, zdravotní pojištění, pojištění invalidity a důchodové pojištění), ochranu zaměstnanců (omezování práce žen a dětí, zákaz práce o nedělích, regulace podniků se zdravotním ohrožením pracujících) a regulaci pracovního práva (standardizace interakce zaměstnance se zaměstnavatelem, obezřetný legislativní přesun od individuálních ke kolektivním pracovním smlouvám, omezení práva na stávku a limitování svobody sdružování dělnictva). Soukromá podnikatelská činnost byla v sociální oblasti regulována, čímž stát de facto korigoval nejrůznější modely průmyslového paternalismu fungující na lokální/firemní úrovni [Ullmann 1995: 173-181].

Jaké důvody motivovaly německé úřady $\mathrm{k}$ formování těchto strategií? Zodpovězení otázky žádá krátkou exkurzi k samotným pojmům „stát blahobytu“ a „sociální stát“, přítomným v německojazyčném prostředí. Ačkoliv byl termín Wohlfahrtsstaat používán v Německu od konce sedmdesátých let 19. století k vyjádření pozitivních konotací $\mathrm{v}$ pečovatelské politice státu o obyvatelstvo a dělnictvo, po první světové válce došlo $\mathrm{k}$ jeho negativnímu zabarvení. Stalo se tak v důsledku agendy národnostních a nacionálních politických uskupení třicátých let, která mobilizovala obyvatelstvo výmarské republiky prostřednictvím kritiky „státu blahobytu“ (Wohlfahrtstaat) coby elementu oslabujícího „morální síly národa“. Negativního zabarvení se pojem Wohlfahrtsstaat nezbavil ani po druhé světové válce, přičemž pozitivně začal naopak být vnímán koncept Sozialstaat [Ritter 1991: 4-14].

Proměny intelektuálního užití slov „stát blahobytu“ a „sociální stát“ lze reprezentativně nahlížet prostřednictvím prestižní německé encyklopedie Der Grosse Brockhaus, která vycházela od konce 18. století až do počátku 21. století. Ta pracovala s termínem „stát blahobytu“ (Wohlfahrtsstaat) teprve v patnáctém vydání z roku 1935. Stručná definice uvádí jen to, že tento legislativní model nevyvíjel aktivity pouze v oblasti vnější a vnitřní ochrany obyvatelstva (právo, armáda), nýbrž také pečoval o jeho blahobyt [Brockhaus 1935: 
418]. Podstatně sofistikovanější definici přinesla šestnáctá edice Der Grosse Brockhaus z padesátých let 20. století, což již souviselo s paradigmatickými proměnami pojmu ve třicátých letech a po skončení druhé světové války. Termín byl striktně rozdělen do dvou podmnožin, a to „stát blahobytu“ (Wohlfahrtsstaat) a „sociální stát“ (Sozialstaat). Wohlfahrtsstaat v sobě skrýval jednak absolutistický model paternalistické závislosti obyvatelstva na centrální administrativě, která využívala donucovací prostř̌edky k dosažení všeobecného blaha (Verwaltungsstaat/Polizeistaat), jednak moderní „stát blahobytu“ založený na „jistotě a disciplíně“ (Versorgungsstaat/Wohlfahrsstaat) [Brockhaus 1957b: 567]. Zatímco „správní/policejní stát“ osvícenského absolutismu údajně vznikl na principech paternalistické závislosti občana vůči státu a použití moci ve prospěch celku, „stát zaopatření/ blahobytu“ čerpal legitimitu ze sociálních jistot. Ty ovšem byly nadřazeny osobní svobodě, od čehož se pak odvíjelo vysoké zdanění populace v kombinaci s obligatorními příspěvky na sociální bezpečnost a ochotou použít monopol státu na moc k zajištění sociálních služeb [Brockhaus 1957b: 567]. Zřetelnou nevýhodou tohoto modelu bylo nebezpečí snížení osobní iniciativy a zodpovědnosti obyvatelstva [Brockhaus 1973: 737]. V ostrém kontrastu ke „státu blahobytu“ byl postaven termín „sociální stát“, kladoucí podstatně větší důraz na osobní svobodu. Stále se jednalo o etatický model zmírňující nerovnosti a sociální pnutí uvnitř populace, prostředkem $\mathrm{k}$ tomuto cíli ovšem byly měkké nástroje finančních transferů. Základ takovéhoto sociálního uspořádání byl tvořen transfery mezi občany navzájem (solidarita), státu vůči celku (sociální péče, prevence a sociální smír) a celku vůči státu (daňové mechanismy) [Brockhaus 1957a: 55-56].

Specifická dichotomie „státu blahobytu“ a „sociálního státu“, patrná mimo jiné i prostřednictvím Der Grosse Brockhaus, vycházela z německé historické zkušenosti s osvícenským absolutismem, nacionálním socialismem a korelovala i s poválečnými diskuzemi o socializaci jakožto nebezpečném kroku k autoritativní společnosti, které se opíraly o nesmírně vlivnou argumentaci předního ekonoma rakouské školy Friedricha von Hayeka (1899-1992) [Hayek 1944]. Uvedená diferenciace byla kompatibilní s rapidním rozvojem ordoliberalismu v západním Německu, někdy označovaného za sociální liberalismus. ${ }^{6}$ Tento teoretický koncept tvořil v západoněmeckém prostředí stěžejní protipól keynesiánským proudům i rakouské ekonomické škole. Ve srovnání s keynesiánským ekonomickým paradigmatem neintervenoval ordoliberální stát do hospodářství s cílem zajistit plnou zaměstnanost, nýbrž stimulovat volnou soutěž a zamezit neefektivní koncentraci výroby (kartelizace, syndikalizace). Přesně v tomto duchu se centralizace ekonomiky v režimu „státu blahobytu“ (Wohlfahrtsstaat) jevila jako nevítané zlo, jemuž bylo třeba se vyvarovat budováním „sociálního státu“ (Sozialstaat). Ordoliberálové však intervencionistickou politiku v sociální sféře zcela neodmítali, jelikož kladli důraz na harmonické propojení ekonomické efektivity a sociální spravedlnosti, čímž nepřímo navázali na některé ze starších odkazů německé historické školy [Yamawaki 2001: 197-199].

Ačkoliv se vyhraněný rozdíl mezi termíny Wohlfahrtsstaat a Sozialstaat v dalších vydáních Der Grosse Brockhaus již neobjevil [Brockhaus 1974: 435-436], po skončení studené války začal být opět kladen důraz na vzájemné diference, a to v souvislosti se snahou o typologizaci odlišných režimů sociálního státu. Pojem Wohlfahrtsstaat se nově

6 Uvést lze základní představitele německého ordoliberalismu, a to Waltera Euckena (1891-1950), Wilhelma Röpkeho (1899-1966), Alfreda Müller-Armacka (1901-1978) a Alexandra Rüstowa (1885-1963). 
ztotožňoval se skandinávským modelem a paternalistickou sociální péčí o občany (stále přitom existovala paralela s již zmíněným pojmem Versorgungsstaat, tedy legislativním modelem, který nadřazoval sociální jistoty osobní svobodě) [Brockhaus 199: 304]. Oproti tomu termín Sozialstaat byl typický pro evropský kontinentální model státních intervencí v sociální sféře, tvořících odpověd’ na industrializaci, urbanizaci a vzrůst chudoby během 19. století. Jeho důležitou charakteristiku tvořila kompatibilita s demokratizací a vznikající občanskou společností [Brockhaus 1993: 556-558]. Totožnou argumentaci předestřely také Vahlens Grosses Wirtschaftslexikon z konce osmdesátých let 20. století i Gabler Wirtschaftslexikon z prvního decennia třetího tisíciletí. Oproti Der Grosse Brockhaus ovšem kladly větší důraz na roli státního intervencionismu v režimu Wohlfahrtsstaat, který - plně v souladu s tehdy převažujícím neoliberálním paradigmatem - představoval nebezpečí pro ekonomickou efektivitu a dynamiku tržních mechanismů [Vahlens 1987: 978-979; Gabler 2004: 3396].

Nástin terminologické diference „státu blahobytu“ (Wohlfahrtsstaat) a „sociálního státu“ (Sozialstaat) je nesmírně důležitý pro porozumění slabé diseminace politickosociologického konstruktu „kapitalismus blahobytu“ (Wohlfahrtskapitalismus) v německojazyčném akademickém a historiografickém prostředí. Ačkoliv pojem Wohlfahrtskapitalismus používala již mladší generace německé historické školy [Balabkins 1993/1994: 36-37], autorem stávající evropské teorie „kapitalismu blahobytu“, kterou hojně převzalo i německojazyčné prostředí, je dánský sociolog Gøsta Esping-Andersen. Nutno podotknout, že se jeho koncept fundamentálně odlišuje od stejnojmenné anglosaské premisy podnikatelských strategií vůči dělnictvu (welfare capitalism). Esping-Andersenova volba tohoto konkrétního termínu se odvíjela z přesvědčení, že existenci sociálního státu na evropském kontinentu předcházely liberální, konzervativní i marxistické debaty o hledání synergií mezi kapitalismem a státní mocí, nikoliv mezi kapitalismem a strategiemi podnikatelů v sociální sféře. Tuto tezi lze doložit na základě autorova zdůvodnění samotného výzkumného záměru jeho vlivné monografie The Three Worlds of Welfare Capitalism z roku 1990:

K sociálnímu státu se přistupovalo úzce i široce. Ti, kteří zaujímají úzký pohled, jej vnímají z hlediska tradičního terénu sociálního zlepšování [...] Široký pohled často rámuje své otázky skrze politickou ekonomii, a soustředuje své zájmy na větší roli státu v řízení a organizování ekonomiky. Proto jsou v širokém pohledu problémy zaměstnanosti, mezd a celkového makroekonomického řízení považovány za integrální komponenty komplexu sociálního státu. V jistém smyslu tento př́stup identifikuje svůj námět jako „Keynesiánský sociální stát“, nebo pokud chcete - „welfare capitalism“"

Esping-Andersen zakončil svou argumentaci zdůvodněním, proč je pro něho pojem „welfare capitalism“ natolik důležitý. Jeho kniha totiž „vnímá sociální stát jako hlavní

Překlad z angličtiny: „The welfare state has been approached both narrowly and broadly. Those who take the narrower view see it in terms of the traditional terrain of social amelioration [...] The broader view often frames its questions in terms of political economy, its interests focused on the state's larger role in managing and organizing the economy. In the broader view, therefore, issues of employment, wages, and overall macro-economic steering are considered integral components in the welfare-state complex. In a sense, this approach identifies its subject matter as the ,Keynesian welfare state` or, if you like, ,welfare capitalism' [...]" [Esping-Andersen 1990: 1-2]. 
instituci v konstrukci rozdílných modelů poválečného kapitalismu. $\mathrm{Z}$ toho důvodu volba jejího titulu $[\ldots]^{\text {“. }} .8$

Jistě není náhodou, že Esping-Andersen postupoval při konstrukci pojmu „Wohlfahrtskapitalismus" obdobně jako mladší generace německé historické školy. Ta si do něho promítla blahobyt, třídní harmonii, loajalitu i vysokou produktivitu kapitalistického systému, kterou ovšem nemohla garantovat pouze ničím nekontrolovaná podnikatelská iniciativa, nýbrž státní moc působící na fungování celého systému [Esping-Andersen 1998: 19-23]. (Již předcházející diskuze nastínila, že se v hlavních intelektuálních proudech německé historické školy hospodářská efektivita nepropojovala ani tak se soukromým sektorem, jako spíše systémovou stabilizací a disciplinací obyvatelstva prostřednictvím podnikového hierarchizace a etatické politiky.) Jádro Esping-Andersenovy argumentace netvořila pouze typologizace sociálního státu na liberální, konzervativní a sociálnědemokratický, ale hlavně konstrukce analytického nástroje „dekomodifikace“ (vytváření legislativních nástrojů za účelem emancipace obyvatel od tržních mechanismů) [Esping-Andersen 1997: 37-38]. Jakkoliv abstraktním se tento termín může jevit, dekomodifikace ve skutečnosti tvoři stěžejní interpretační nástroj, který umožňuje nahlížet německý diskurz kapitalismu i sociální strategie Německa ve zcela nové perspektivě. Sociální a mocenská interakce mezi podnikatelem a jeho personálem mimo rámec běžné pracovní smlouvy spojená $\mathrm{s}$ vytvořením paternalistické závislosti dělnictva na zaměstnavateli (tj. průmyslový paternalismus) [Berghoff 1997: 167-204], nemohla být pro tvůrce sociálního státu bismarckovského a wilhelmovského Německa zcela žádoucí, jelikož narušovala vazby mezi centrální administrativou a jejími subjekty. Dokonce ani v poválečném období se západoněmecký ordoliberální sociální stát nesnažil zpřetrhat synergii sociální politiky a státních intervencí [Borchert - Lessenich 2012: 293-294], ačkoliv odmítal administrativní centralizaci socioekonomického systému, typickou pro absolutistický režim Wohlfahrtsstaat i anglosaský (beweridgeovský) a skandinávský model welfare state. Jestliže měl občan disciplinovaně respektovat pravidla, potřeboval se za toto chování dočkat patřičné odměny, která se ale z legitimizačních důvodů státní administrativy neměla odvíjet jen od soukromé podnikatelské iniciativy, nýbrž i ze strategií úřadů. Stávající německé historiografické uchopení termínu Wohlfahrtskapitalismus vystihuje právě tento moment - dárcem sociálních benefitů nemá být výhradně podnikatel, nýbrž také stát [Ullmann 1979: 574-610; Ullmann 1981: 133-149].

Samozřejmě nelze výše nastíněnou tezi akceptovat bezvýhradně, jelikož př́liš zjednodušuje početné historiografické přístupy k nesmírně komplexní interakci mezi státem, podnikatelem a dělníkem v bismarckovské a wilhelmovské éře [Rassem 1992: 632-634]. Tehdejší německý stát byl ve skutečnosti konglomerátem mnoha protichůdných názorových a mocenských proudů, což úřadům znemožňovalo konstruování zcela koherentních a dlouhodobě konsistentních strategií vůči podnikatelstvu a dělnictvu [Ullmann 1976: 112-113]. Stát do interakce zaměstnavatel - zaměstnanec aktivně vstupoval, nesnažil se ovšem výrazně znevýhodnit jednoho či druhého, nýbrž posunout celý systém do takové roviny, která by odpovídala partikulárním i strategickým zájmům aktérů, kteří tvořili jeho aparát. $\mathrm{V}$ praxi to nemuselo značit vzájemný konflikt s podnikatelským prostředím,

Překlad $\mathrm{z}$ angličtiny: „The book, then, sees the welfare state as a principal institution in the construction of different models of post-war capitalism. Hence the choice of its title [...]" [Esping-Andersen 1990: 5]. 
nýbrž synergetickou kooperaci. Soukromé podnikání v Německu ostatně nepředstavovalo snadný terč, jelikož se jakožto protipól státního intervencionismu kolektivně sdružilo roku 1895 do zájmové organizace Bund der Industriellen, která se stala nositelem svébytných lobbingových strategií disponujících značným vlivovým potenciálem [Ullmann 1976: 91]. Mocenské soupeření ostatně ani nebylo něčím, co mohlo státu přinést v dlouhodobé perspektivě podstatné výhody. Př́má participace soukromníka na sociální politice skrze budování „zařízení blahobytu“ (Wohlfahrtseinrichtungen) byla žádoucí i z toho důvodu, že slibovala umenšit fiskální závazky státu na volnočasové aktivity, zdravotní péči a vzdělávání dělnictva. „Průmyslový paternalismus“ ovšem nesměl přerůst ve vznik autonomní kapitalistické soustavy, ze které by byl vyloučen stát jakožto závěrečná regulativní instance a arbiter sporů. I proto státní úřady vytvářely od přelomu 19. a 20. století mechanismy legislativního dozoru, které měly zčásti motivovat, zčásti donutit soukromé podnikatelské subjekty k respektování sociálního konsenzu, jehož konečnou podobu definuje státní moc.

\section{Závěrečné teze: Wohlfahrtskapitalismus v německé historiografii}

Jak se uvedená specifika německého pojetí „kapitalismu blahobytu“ (Wohlfahrtskapitalismus) podepsala na historiografické interpretaci tohoto fenoménu? Na základě uvedené argumentace lze nastínit dvě základní teze, tvořící součást specifického německého modelu Wohlfahrtskapitalismus:

1. Stát jakožto nositel sociální emancipace: německý diskurz kapitalismu od počátku kladl důraz na mimořádnou úlohu intervencí v hospodářském životě, a to v korelaci s osvícensko-absolutistickými tradicemi státu „pořádku a blahobytu“ (Ordnungs- und Wohlfahrtsstaat). Takovéto myšlenkové podhoubí ani nemohlo vygenerovat dominantní ekonomickou koncepci, jež by státu odepřela angažovanost v sociální politice, což se odrazilo také v německé historiografii hospodářských a sociálních dějin. Se státními intervencemi nebyl korporátní sektor spokojený hned ze dvou důvodů - menší firmy se bránily zavádění sociální legislativy „shora“ kvůli rostoucím nákladům na pracovní sílu a větší podniky zase protestovaly vưči limitování jejich paternalistického modelu sociálních zařízení (Wohlfahrtseinrichtungen), která pracně vybudovaly iniciativou „zdola“ (dichotomie malé - velké podnikatelské subjekty ale rozhodně nefungovala univerzálně, jelikož do hry vstupovaly ještě další faktory jako třeba vlastnická struktura či specifika konkrétního výrobního odvětví). Navzdory tomu se koncem 19. století pozvolna utvořil dvojkolejný systém sociálního zabezpečení podnikatel stát (při zahrnutí organizační činnosti samotného dělnictva a aktivit dalších aktérů), jehož těžiště se dlouhodobě přesouvalo ke státu a jeho legislativní iniciativě.

2. Stát jakožto garant sociální emancipace: intervencionistická politika v sociální sféře se zpočátku přizpůsobovala potřebám soukromého sektoru a spíše doporučovala, než aby přikazovala. Avšak postupující industrializace stupňovala normativní opatření v legislativní rovině, mezi jejichž cíle patřilo jednak plošné řešení dělnické otázky, jednak ideologické ubezpečení občanů o akceschopnosti administrativy zajistit jejich blahobyt. Pokračující „outsorcing“ sociální politiky na úroveň průmyslových podniků se v tomto kontextu nemohl jevit zdaleka tak žádoucím jako v anglosaských zemích, jež přenechávaly soukromé iniciativě stěžejní roli v socioekonomické modernizaci. Středoevropský stát si jen stěží dokázal nárokovat monopol na sociální péči o dělnictvo, 
což ovšem neznamená, že by se tohoto ideálu alespoň nepokusil v ideologické rovině dosáhnout. Státní intervence tak bezděky překryly systémový význam podnikatelských strategií při vytváření sofistikovaného sociálního řetězce na úrovni konkrétních firem. Přesně v tomto duchu pozdější německý historiografický diskurz „Wohlfahrtskapitalismus“ upozadil úlohu soukromé sociální iniciativy jakožto tvưrce svébytného socioekonomického systému a naopak vyzdvihl strategie státu.

$$
* * *
$$

Dle výše nastíněných tezí je pochopitelné, že se v německé historiografii nerozvinul natolik komplexní teoretický koncept propojující podnikatelské chování se sociálním zabezpečením dělnictva, jako se tomu stalo v anglosaských zemích. Podnikatelé vskutku byli nositeli specifických strategií, které cílily na kultivování dělnického prostředí, reklamní reprezentaci, zvýšení lidského kapitálu a zajištění paternalistické závislosti zaměstnanců (zejména v oborech vyžadujících kvalifikovanou pracovní sílu, o kterou byla na trhu práce nouze). Existující německá literatura si ovšem nekladla za cíl analyzovat tyto nástroje coby souhrnný celek, jelikož to nebyli ani tak podnikatelé jako spíše státní administrativa, jež měla ideologické ambice vytvořit sofistikovaný systém péče o dělnictvo jakožto součást koncepce „státu blahobytu“ (Wohlfahrtsstaat).

\section{Poděkování}

Tento text je výsledkem standardního projektu č. 18-03921S, Sociální otázka in situ: sociální politika průmyslových podniků v českých zemích, 1879-1914, který podpořila Grantová agentura České republiky.

\section{Literatura}

Backhaus, Jürgen H. [1993/1994]. Gustav Schmoller and the Problems of Today. History of Economic Ideas 1/2 (3/1): 3-25.

Balabkins, Nicholas W. [1993/1994]. Gustav Schmoller and the Emergence of Welfare Capitalism. History of Economic Ideas 1/2 (3/1): 27-42.

Berghoff, Hartmut [1997]. Unternehmenskultur und Herrschaftstechnik. Industrieller Paternalismus: Hohner von 1857 bis 1918. Geschichte und Gesellschaft 23 (2): 167-204.

Blasius, Dirk [1971]. Lorenz von Steins Lehre vom Königtum der sozialen Reform und ihre verfassungspolitischen Grundlagen. Der Staat 10 (1): 33-51.

Borchert, Jens - Lessenich, Stephan [2012]. Staat - Kapitalismus - Demokratie: Einführung und weiterführende Literatur. In. Borchert, Jens - Lessenich, Stephan (ed.). Der Vergleich in den Sozialwissenschaften: Staat - Kapitalismus - Demokratie. Frankfurt - New York: Campus Verlag, s. 285-304.

Braudel, Fernand [1979]. Civilization and Capitalism 15th-18th Century. Vol. 1-3. New York: Harper \& Row.

Braudel, Fernand [1985]. La Dynamique du Capitalisme. Paris: Flammarion.

Braudel, Fernand [1999]. Dynamika kapitalismu. Praha: Argo.

Brockhaus Enzyklopädie [1972]. Bd. 14. Auflage 17. Wiesbaden: Brockhaus.

Brockhaus Enzyklopädie [1973]. Bd. 17. Auflage 17. Wiesbaden: Brockhaus.

Brockhaus Enzyklopädie [1974]. Bd. 20. Auflage 17. Wiesbaden: Brockhaus.

Brockhaus Enzyklopädie [1993]. Bd. 20. Auflage 19. Mannheim: Brockhaus.

Brockhaus Enzyklopädie [1994]. Bd. 24. Auflage 19. Mannheim: Brockhaus.

Der Grosse Brockhaus [1957a]. Bd. 11. Auflage 16. Wiesbaden: Brockhaus. 
Der Grosse Brockhaus [1957b]. Bd. 12. Auflage 16. Wiesbaden: Brockhaus.

Der Grosse Brockhaus: Handbuch des Wissens in zwanzig Bände [1935]. Bd. 20. Auflage 15. Leipzig: Brockhaus.

Dworkin, Gerald [2017]. Paternalism. Stanford Encyclopedia of Philosophy. Dostupné z: <https://plato .stanford.edu/entries/paternalism> [18. 8. 2019].

Ellerkamp, Marlene [1991]. Industriearbeit, Krankheit und Geschlecht: Zu den sozialen Kosten der Industrialisierung Bremer Textilarbeiterinne 1870-1914. Göttingen: Vandenhoeck \& Ruprecht.

Engelhardt, Werner E [2001]. Sozial- und Gesellschaftspolitik - grundlagenbezogen diskutiert. Berlin: Duncker \& Humblot.

Esping-Andersen, Gøsta [1990]. The Three Worlds of Welfare Capitalism. Princeton - Cambridge: Princeton University Press.

Esping-Andersen, Gøsta [1998]. Die drei Welten des Wohlfahrtskapitalismus: Zur politischen Ökonomie des Wohlfahrtsstaates. In. Lessenich, Stephan - Ostner, Hana (ed.). Welten des Wohlfahrtskapitalismus: Der Sozialstaat in vergleichender Perspektive. Frankfurt - New York: Campus Verlag, s. 19-56.

Gabler Wirtschafts Lexikon [2004]. Bd. S-Z. Auflage 16. Wiesbaden: Gabler.

Griffis, William Elliot [1910]. The Statesmanship of Ito. The North American Review 650 (191): 114-127.

Hayek, Friedrich von [1944]. Road to Serfdom. Chicago: University of Chicago Press.

Herc, Svatopluk [2020]. Welfare kapitalismus: koncepty a motivace podnikatelů při řešení sociální otázky, 1900-1930. Historická sociologie (2): 87-106.

Hilgert, Marie-Elisabeth [1982]. Kapital, Kapitalist, Kapitalismus. In. Otto Brunner - Werner Conze Reinhart Koselleck (ed.). Geschichtliche Grundbegriffe: Historisches Lexikon zur politisch-sozialen Sprache in Deutschland. Bd. 3. Stuttgart: Klett-Cotta, s. 399-454.

Howard, M. C. [1985]. Fernand Braudel on Capitalism: A Theoretical Analysis. Historal Reflections / Réflexions Historiques 3 (12): 469-483.

Kocka, Jürgen [2013]. Geschichte des Kapitalismus. Bonn: Bundeszentrale für politische Bildung.

Kocka, Jürgen [2016]. Introduction. In. Kocka, Jürgen - Linden, Marcel van der. Capitalism: The Reemergence of a Historical Concept. London - Oxford - New York - New Delhi - Sydney: Bloomsbury, s. $1-10$.

Kromphardt, Jürgen [2015]. Analysen und Leitbilder des Kapitalismus von Adam Smith bis zum Finanzkapitalismus. Marburg: Metropolis Verlag.

Linden, Marcel van der [2011]. Ein globalgeschichtlicher Blickwinkel auf Kapitalismus und Arbeiterklasse. In. Budde, Gunilla (ed.). Kapitalismus: Historische Annäherungen, Göttingen, s. 164.

Morishima, Michio [1982]. Why has Japan „Succeeded“?: Western Technology and the Japanese Ethos. Cambridge - London - New York - New Rocehlle - Melbourne - Sydney: Cambridge University Press.

Nakane, Chie [1970]. Japanese Society. Berkeley - Los Angeles: University of California Press.

Quack, Sigrid [2006]. Die transnationalen Ursprünge des „deutschen Kapitalismus“. In. Berghahn, Volker R. - Vitols, Sigurt (ed.). Gibt es einen deutschen Kapitalismus? Tradition und globale Perspektiven der sozialen Marktwirtschaft. Frankfurt - New York: Campus Velag, s. 63-86.

Rákosník, Jakub - Tomeš, Igor [2012]. Sociální stát v Československu: Právně-institucionální vývoj v letech 1918-1992. Praha: Auditorium.

Rákosník, Jakub [2010]. Sovětizace sociálního státu: Lidově demokratický režim a sociální práva občanů $v$ Československu 1945-1960. Praha: Filozofická fakulta Univerzity Karlovy.

Rákosník, Jakub [2012]. Historie pojmu „sociální stát“ v Čechách. In. Čechurová, Jana - Andrš, Pavel Velek, Luboš (ed.). Posláním historik: Pocta prof. Robertu Kvačkovi k 80. narozeninám. Praha: Nakladatelství lidové noviny - Filozofická fakulta Univerzity Karlovy, s. 323-338

Rassem, Mohammed [1992]. Wohlfahrt, Wohltat, Wohltätigkeit, Caritas. In. Otto Brunner - Werner Conze - Reinhart Koselleck (ed.). Geschichtliche Grundbegriffe: Historisches Lexikon zur politisch-sozialen Sprache in Deutschland. Bd. 7. Stuttgart : Klett-Cotta, s. 595-636.

Ritter, Gerhard A. [1991]. Der Sozialstaat: Entstehung und Entwicklung im internationalen Vergleich. Zweite Auflage. München: R. Oldenbourgh Verlag.

Schieder, Wolfgang [1984]. Sozialismus. In. Otto Brunner - Werner Conze - Reinhart Koselleck (ed.). Geschichtliche Grundbegriffe: Historisches Lexikon zur politisch-sozialen Sprache in Deutschland. Bd. 5. Stuttgart : Klett-Cotta, s. 923-996. 
Schneider, Dieter. [1993/1994]. Schmoller and the Theory of the Corporation and of Corporate Control. History of Economic Ideas 1/2 (3/1): 3-25.

Schröter, Harm G [2013]. Cartels Revisited: An Overview on Fresh Questions, New Methods, and Surprising Results. Revue économique 64 (6): 989-1010.

Sombart, Werner [1902-1928]. Der moderne Kapitalismus: Historisch-systematische Darstellung des gesamteuropäischen Wirtschaftslebens von seinen Anfängen bis zur Gegenwart. Bd. 1-3. München - Leipzig: Duncker \& Humblot.

Ullmann, Hans Peter [1976]. Der Bund der Industriellen. Organisation, Einfluss und Politik klein- und mittelbetrieblicher Industrieller im Deutschen Kaiserreich 1895-1914. Göttingen: Vandenhoeck \& Ruprecht.

Ullmann, Hans Peter [1995]. Das Deutsche Kaiserreich 1871-1918. Frankfurt am Main: Suhrkamp Verlag.

Ullmann, Hans-Peter [1979]. Industrielle Interessen und die Entstehung der deutschen Sozialversicherung 1880-1889. Historische Zeitschrift 229 (3): 574-610.

Ullmann, Hans-Peter [1981]. German Industry and Bismarck's Social Security System. In. Mommsen, Wolfgang (ed.). The Emergence of the Welfare State in Britain and Germany: 1850-1950. London - New York: Croom Helm, pp. 133-149.

Vahlens Grosses Wirtschaftslexikon [1987]. Bd. 2. München: C. H. Beck - Franz Vahlen.

Wehler, Hans-Ulrich [2011]. Die Deutschen und der Kapitalismus. In. Budde, Gunilla (ed.), Kapitalismus: Historische Annäherungen. Göttingen: Vandenhoeck \& Ruprecht.

Yamawaki, Naoshi [2001]. Walter Eucken and Wilhelm Röpke: A Reappraisal of their Economic Thought and the Policy of Ordoliberalism. In. Shionoya, Yuichi (ed.). The German Historical School: The Historical and Ethical Approach to Economics. London - New York: Routledge, s. 188-201.

Zudová-Lešková, Zlatica - Voráček, Emil [2014]. Theory and Practice of the Welfare State in the 20th and the Early 21st Century. In. Zudová-Lešková, Zlatica - Voráček, Emil (ed.). Theory and Practice of the Welfare Statein Europe in 20th Century. Prague: The Institute of History, Academy of Sciences of the Czech Republic, s. 11-45.

Tomáš Gecko je absolventem doktorského programu Moderních hospodářských a sociálních dèjin na Ústavu hospodářských a sociálních dějin FF UK. Zaměř̀je se na dějiny podnikání, monopolizaci trhu, mezinárodní vztahy a dějiny vědy. 